\title{
Discovery of Euglossa (Euglossa) cognata Moure (Apidae: Euglossini) in the Platina Basin, Mato Grosso state, Brazil
}

\author{
Evandson José dos Anjos-Silva ${ }^{1,2,3}$ \\ ${ }^{I}$ Departamento de Biologia, Universidade do Estado de Mato Grosso - UNEMAT, \\ CP 242, CEP 78200-000, Cáceres, MT, Brazil \\ ${ }^{2}$ Programa de Pós-Graduação em Ecologia e Conservação da Biodiversidade, Instituto de Biociências, \\ Universidade Federal de Mato Grosso - UFMT, \\ Avenida Fernando Corrêa da Costa, s/n, CEP 65025-650, Cuiabá, MT, Brazil \\ ${ }^{3}$ Corresponding author: Evandson José dos Anjos-Silva, e-mail: evandson@usp.br
}

ANJOS-SILVA, E.J. DOS 2008. Discovery of Euglossa (Euglossa) cognata Moure (Apidae: Euglossini) in the Platina Basin, Mato Grosso state, Brazil. Biota Neotrop. 8(2): http://www.biotaneotropica.org.br/v8n2/ en/abstract?article+bn01208022008.

Abstract: By attracting male orchid bees with eight chemical baits in the gallery forest of the Parque Nacional da Chapada dos Guimarães, southern Mato Grosso state, Brazil, I found several males belongs to all Euglossini bee genera. Male euglosine bees were collected monthly using an entomological net as they arrived at the baits. From September 2003 to July 2005, the baits were applied to absorbent paper pads from 8:00 AM to 4:00 PM. From 24 collections, a total of 264 males were captured, spread throughout the five genera of the tribe and belonging to 30 valid species. Of all the males collected, only one was Euglossa cognata Moure, reported to occur from Costa Rica to southern Brazil, and herein recorded to the Platina Basin for the first time. The results clarify the distributional gap and amplified the geographic distributional range of E. cognata in South America. Keywords: orchid bees, Euglossa, analis group, geographic distribution, Platina Basin, neotropics.

ANJOS-SILVA, E.J. DOS 2008. Descoberta de Euglossa (Euglossa) cognata Moure (Apidae: Euglossini) na Bacia Platina, Mato Grosso, Brasil. Biota Neotrop. 8(2): http://www.biotaneotropica.org.br/v8n2/pt/ abstract?article+bn01208022008.

Resumo: Oito iscas-odores foram utilizadas para atrair machos das abelhas Euglossini na floresta de galeria do Parque Nacional da Chapada dos Guimarães, sul de Mato Grosso. De setembro de 2003 a julho de 2005, uma vez por mês, das 08:00 às 16:00 horas, os machos foram capturados conforme chegavam às iscas-odores. Durante as 24 coletas, foram capturados 264 machos, distribuídos pelos cinco gêneros da tribo e pertencentes a 30 espécies válidas. Do total de machos coletados, apenas um era de Euglossa cognata Moure, espécie com distribuição geográfica desde a Costa Rica até o sudeste do Brasil, todavia sem registro anterior para a Bacia Platina. O resultado aqui apresentado amplia a distribuição geográfica de E. cognata na América do Sul.

Palavras-chave: abelhas das orquídeas, Euglossa, grupo analis, distribuição geográfica, Bacia Platina, neotrópico. 


\section{Introduction}

The tribe Euglossini Latreille 1802 (Anthophila: Apidae: Apinae: Euglossini) comprises five genera, Eulaema Lepeletier de Saint Fargeau 1841, Euglossa Latreille 1802, Eufriesea Cockerell 1908, free-living bees, and Exaerete Hoffmannsegg 1817 and Aglae Lepeletier de Saint Fargeau \& Audinet-Serville 1825, cleptoparasitic on other orchid bees, the former of Eulaema and Eufriesea and the late of Eulaema (Myers 1935, Bennett 1972, Garófalo \& Rozen 2001). The family-group names for bees followed the proposition of Michener (2000) and (Engel 2005).

The bees of the genus Euglossa Latreille, 1802 are known to occur from Mexico to northern Argentina (Moure 1967, Dressler 1982a, Ramírez et al. 2002, Roubik \& Hanson 2004). This genus has been divided into six subgenera, according to Dressler (1978a, 1982b) and Moure (1969, 1970, 1989a, 1989b): Glossura Cockerell, Glossurella Dressler, Dasystilbe Dressler, Euglossella Dressler, Glossuropoda Moure, and Euglossa sensu stricto Latreille, all synonymized under Euglossa by Michener (2000). For the purpose of this study, I maintained this subgenus classification of Moure's and Dressler's works. The subgenus Euglossa sensu stricto is the richest in number of species (Rebêlo \& Moure 1995, Roubik 2004, Roubik \& Hanson 2004), the majority of which were described by Moure (1967, 1968, 1969, 1970, 1989a, b, 1989b) and Dressler (1978a, b, 1982a, b, c, d, 1985), with 39 and 37 valid species, respectively. There are 117 valid species described for the genus Euglossa (Moure \& Schlindwein 2002, Ramírez 2005, 2006, Rasmussen \& Skov 2006 , Parra-H. et al. 2006, Hinojosa-Díaz \& Engel 2007a, b), 57 of which belong to the subgenus Euglossa, and of these 7 species were included to the analis species group (see Dressler, 1982b).

E. cognata Moure, 1970 belongs to the subgenus Euglossa sensu stricto (Ramírez et al. 2002), however this species was initially included in the subgenus Euglossella by Moure (1970). The holotype is a male collected in 1953 in Mocajuba, Mangabeira, in the state of Pará, and several males from Óbidos, Monte Pascoal Reserve and Córrego Itá, Conceição da Barra, in the Brazilian states of Pará, Bahia and Espírito Santo, respectively. According to existing literature, the E. cognata occurs from Central America (Honduras to Panama and Trinidad \& Tobago) (Moure 1970, Williams \& Dodson 1972, Janzen et al. 1982, Ackerman 1983, 1989, Dressler 1985 , Pearson \& Dressler 1985, Roubik \& Ackerman 1987, Ramírez et al. 2002, Roubik \& Hanson 2004) to northern Brazil (Morato et al. 1992, Oliveira 1999, Oliveira \& Campos 1996) and southern Brazil (Peruquetti et al. 1999). E. cognata males have been attracted to methyl salycilate (Williams \& Dodson 1972, Pearson \& Dressler 1985, Ackerman 1989, Janzen et al. 1982, Morato et al. 1992, Silva \& Rebêlo 1999, Anjos-Silva 2006a), cineole (Pearson \& Dressler 1985, Ackerman 1989), eugenol (Pearson \& Dressler 1985), benzyl acetate (Ackerman 1989, Janzen et al. 1982), methyl benzoate, methyl cynnamate and skatol (Ackerman 1989), vanillin (Janzen et al. 1982, Roubik \& Hanson 2004), benzyl benzoate, p-dimethoxi benzene and beta ionone (Eltz et al. 1999, Ramírez et al. 2002).

\section{Material and Methods}

This study was conducted in the gallery forest of the Véu de Noiva valley in the Chapada dos Guimarães National Park (15 $24^{\prime} 21^{\prime \prime} \mathrm{S}$ and 55 50' 12" W), southern State of Mato Grosso. The Planalto dos Guimarães is the natural boundary between the Amazon, Platina and Araguaia basins and represents the extreme northeastern boundaries of the Alto Paraguai basin, the altitude of which ranges from 300 to $836 \mathrm{~m}$, annual rainfall from 1750 to $2000 \mathrm{~mm}$, and annual temperature from 13 to $30{ }^{\circ} \mathrm{C}$ (PCBAP 1997). The basement rock in the subject area is all sandstone. From September 2003 to July 2005, male euglossine bees were collected monthly with an insect collecting net as they arrived at the chemical baits. A total of eight compounds were used: benzyl benzoate, 1.8 - cineole, eugenol, vanillin, methyl acetate, methyl cinnamate, methyl salicylate and benzyl acetate. The baits were simultaneously applied to absorbent paper pads from 8:00 AM to 4:00 PM. These paper pads were set $5.0 \mathrm{~m}$ apart from each other, suspended from twigs by a string $1.5 \mathrm{~m}$ above the ground. The paper pads were replenished every 60 minutes with $1 \mathrm{~mL}$ of chemical to prevent losses due to their volatility. Males collected were placed in a killing jar containing ethyl acetate and then transferred to plastic vials. Methodology and analysis followed the procedures employed in Anjos-Silva (2006b). A voucher specimen of E. cognata was deposited in the collection of the Departamento de Biologia da Faculdade de Filosofia, Ciências e Letras de Ribeirão Preto - USP (RPSP). The aim of this study is to record, for the first time, the presence of E. cognata in the Platina Basin, and its occurrence in the gallery forest of Central Brazil.

\section{Results and Discussion}

In the first year, the baits attracted 177 males distributed among four genera and 21 valid species: Eufriesea (3 species), Euglossa (14 species), Exaerete (1 species) and Eulaema (3 species). In the second year, 87 males belonging to 20 valid species and five genera were collected: Eufriesea (3 species), Euglossa (10 species), Exaerete (2 species) (Anjos-Silva \& Rebêlo 2006), Eulaema (4 species) (Anjos-Silva 2007) and Aglae (1 species) (Anjos-Silva et al. 2006). Of the 87 males captured, a single male correspond to E. cognata, attracted to methyl salycilate in July 2005, in the middle of the dry season (Anjos-Silva 2006a, b).

In the Central America, a number of surveys have reported the presence of $E$. cognata (the number of males collected is shown in parentheses): Williams \& Dodson (1972) $(\mathrm{N}=1$ §), Janzen et al.

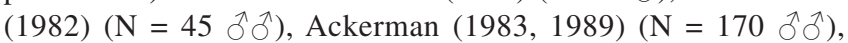
Pearson \& Dressler (1985) $(\mathrm{N}=70 \hat{\jmath})$, Roubik \& Ackerman (1987) $\left.\left(\mathrm{N}=9 \delta^{\top}\right)^{\top}\right)$, which can be compared to the site collections in Brazil, with the following results: Morato et al. (1992) $\left(\mathrm{N}=2 \delta^{\lambda} \delta^{\lambda}\right)$,

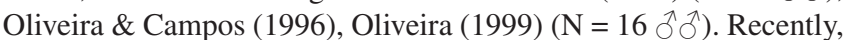
this species was reported to occur in the state of Mato Grosso (Anjos-Silva 2006a), but only one male was collected at this site in Central Brazil. So, the number of males collected varies substantially in the neotropics. Based on the existing literature, and my research in the Cerrado domains in Central Brazil (Anjos-Silva 2006b), I suggest that this species is a rare species in the gallery forest, particularly in the Chapada dos Guimarães Park where this study was done.

This species can be easily distinguished among the analis species group by the middle tibia which has just one, comma-shaped tuft (Figure 1), rather than a bean-shaped or deeply notched tuft as in E. analis Westwood, 1840 and E. iopyrrha Dressler, 1982a respectively. Many authors had reported the occurrence of the E. cognata with a broader geographic distribution, but with discontinuities in the Cerrado domains. However the record here reported modifies that distribution (Figures 2, 3 and 4). The results reveal that i) the geographical distribution of E. cognata is not as disjunct in the neotropics as once thought, ii) that the E. cognata is a rare species in the Platina Basin, and also in the Amazon and South Atlantic Basin - East portion. In contrast, based on the surveys in the last four decades (see infra) in Central America, E. cognata was seen as one of the most abundant species in the tropical forest bee communities of Barro Colorado Island, where Ackerman (1989) collected $170 \widehat{\partial} \delta$ during a single year. Before the present study, the presence of E. cognata had not been reported in the Platina Basin, where this species occurs in sympatry with other species of the analis group, such as E. analis, E. bidentata Dressler, 1982a and 


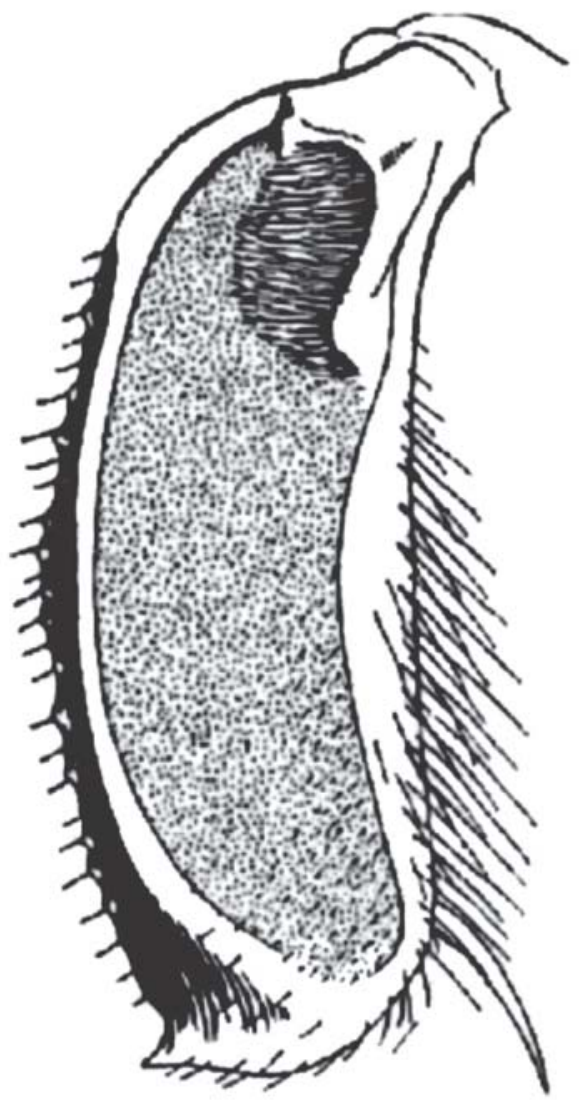

Figure 1. The velvety area and the middle tibia with just one, commashaped tuft, a peculiar feature of the E. cognata males. Redraw from Moure (1970).

Figura 1. Área aveludada da face externa da tíbia mesotorácica com apenas um coxim, em forma de vírgula, uma característica peculiar dos machos de E. cognata. Redesenhado de Moure (1970).

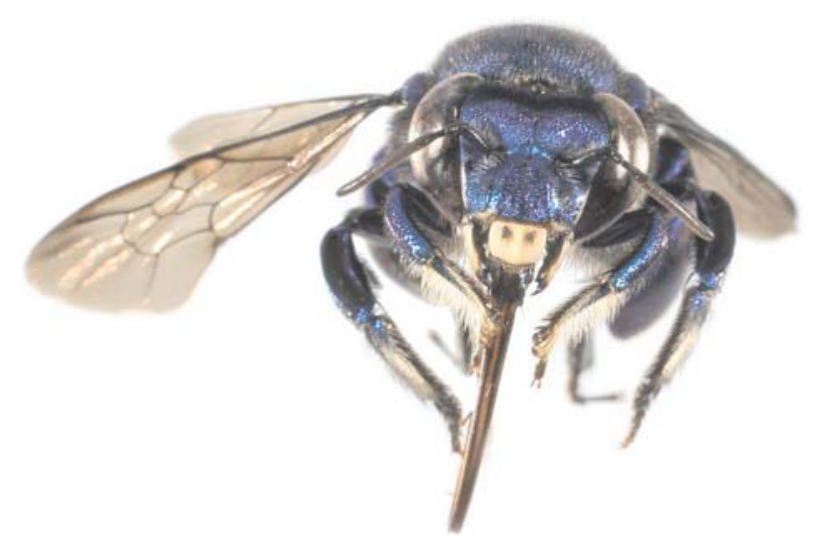

Figure 2. Frontal view of E. cognata male from the Platina Basin, showing the dark bluish tegument on the face and vertex, completely blue clypeus, cream white mandibles but black teeth, and two small translucid spots

Figura 2. Vista frontal do macho de E. cognata da Bacia Platina, exibindo o tegumento azul escuro na face no vértice, clípeo completamente azul, mandíbulas com manchas branco-marfim, mas com dentes enegrecidos, e dois pequenos pontos translúcidos.

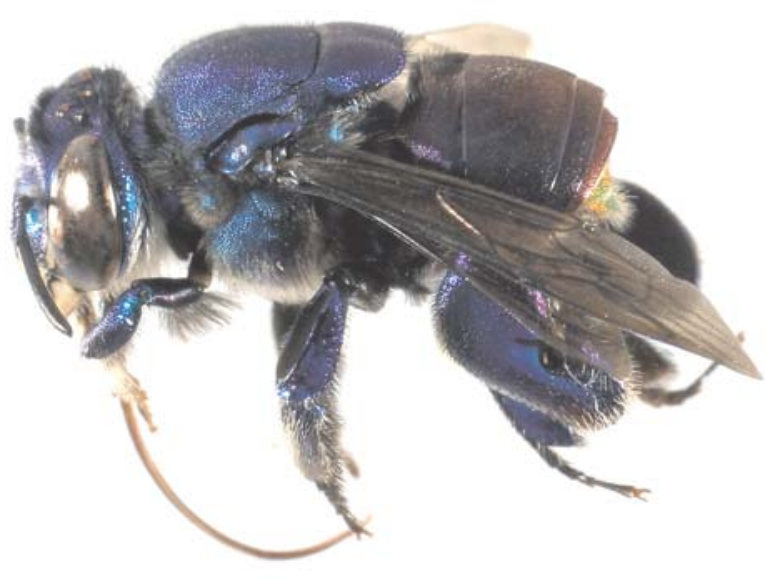

Figure 3. Lateral habitus of E. cognata male, from the Platina Basin.

Figura 3. Hábito lateral do macho de E. cognata, da Bacia Platina.

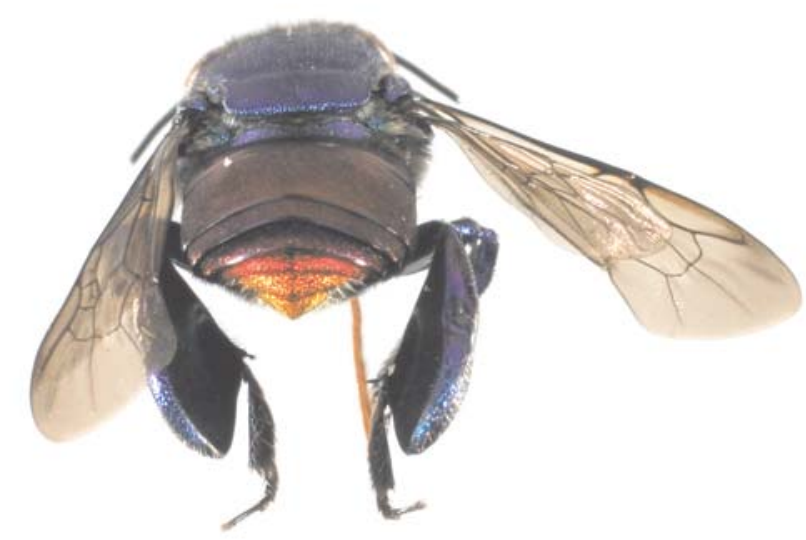

Figure 4. Rear view of E. cognata male from the Platina Basin, showing the colors of the terminal segments.

Figura 4. Vista da porção posterior do macho de E. cognata da Bacia Platina, exibindo as cores dos segmentos terminais.

E. iopyrrha. This gap is a consequence of the poor knowledge about the Cerrado euglossine fauna. This hypothesis is reinforced by the results obtained by Anjos-Silva et al. (2006), who collected Aglae caerulea Lepeletier \& Serville, 1825, a species previously indicated as endemic to the Amazon Basin (Moure 1967a, b, Michener 2000, Cameron 2004), in the Chapada dos Guimarães National Park, increasing its known geographical distribution by approximately 2,400 kilometers southward in South America. Furthermore, the hypothesis is also reinforced by the recent results obtained by Anjos-Silva (2007), who collected Eulaema pseudocingulata Oliveira, 2006, another species previously also indicated as endemic to the Amazon Basin (Oliveira 2006), in the Platina Basin, where this species occurs in sympatry with E. cingulata (Fabricius 1804), a sibling species of similar morphology and color pattern but with a broader geographic distribution. These results amplified 
the geographical distribution range of E. cognata in South America and the species, together with A. caerulea and E. pseudocingulata, is now recorded in both the Amazon and Platina Basins. Therefore, although the presence of E. cognata in the Chapada dos Guimarães Park may be seen as surprising, its occurrence there represents just one more example of the Amazon and Atlantic forest's influence on the composition of the Cerrado domain fauna.

\section{Acknowledgements}

Support was provided by a CAPES research grant PQI 0053/02-3, while CNPq EU 473857/03-0 generously supported the work in the FFCLRP/USP. I thank Dr. Evandro Camillo and Dr. Carlos Alberto Garófalo from Universidade de São Paulo FFCLRP-USP, and the Departamento de Biologia, at Universidade de Mato Grosso UNEMAT, for support, and two anonymous reviewers for providing useful comments.

\section{References}

ACKERMAN, J.D. 1983. Diversity and seasonality of male euglossine bees (Hymenoptera: Apidae) in Central Panama. Ecology 63(2):274-283.

ACKERMAN, J.D. 1989. Geographic and seasonal variation in fragrance choices and preferences of male euglossine bees. Biotropica 21(4):340-347.

ANJOS-SILVA, E.J dos. 2006a. Orchid bee species from Mato Grosso: An appraisal. Anais do VII Encontro sobre Abelhas, USP, Ribeirão Preto, 12-15 de julho, p.503-509. http://ww.rge.fmrp.usp.br/abelhudo (último acesso em 10/10/2007).

ANJOS-SILVA, E.J dos. 2006b. Fenologia das abelhas Euglossini Latreille (Hymenoptera: Apidae) e a variação sazonal e geográfica na escolha e preferência por iscas-odores no Parque Nacional de Chapada dos Guimarães e na Província Serrana de Mato Grosso, Brasil. Tese de doutorado, Universidade de São Paulo, Ribeirão Preto. http://www. teses.usp.br/teses/disponiveis/59/59131/tde-10072007-112922/ (último acesso em 10/10/2007)

ANJOS-SILVA, E.J dos. 2007. Occurrence of Eulaema (Apeulaema) pseudocingulata Oliveira (Hymenoptera: Apidae: Euglossini) in the Platina Basin, Mato Grosso state, Brazil. Neotrop. Entomol. 36(3):484-486. http://www.scielo.br/pdf/ne/v36n3/22.pdf (último acesso em 10/10/2007).

ANJOS-SILVA, E.J. dos, CAMILLO, E. \& GARÓFALO, C.A. 2006 Occurrence of Aglae caerulea Lepeletier \& Serville (Hymenoptera: Apidae: Euglossini) in the Parque Nacional da Chapada dos Guimarães, Mato Grosso State, Brazil. Neotrop. Entomol. 35(6):868-870. http://www. scielo.br/pdf/ne/v35n6/a24v35n6.pdf (último acesso em 10/10/2007)

ANJOS-SILVA, E.J. dos \& REBÊLO, J.M.M. 2006. A new species of Exaerete Hoffmannsegg (Hymenoptera: Apidae: Euglossini) from Brazil. Zootaxa 1105:27-35. http://www.mapress.com/zootaxa/2006f/z01105p035f.pdf (último acesso em 10/10/2007).

BENNETT, F.D. 1972. Observations on Exaerete spp. and their hosts Eulaema terminata and Euplusia surinamensis (Hymen., Apidae, Euglossinae) in Trinidad. J.N.Y. Entomol. Soc. 80:118-124.

CAMERON, S.A. 2004. Phylogeny and biology of Neotropical orchid bees (Euglossini). Ann. Rev. Entomol. 49:377-404.

COCKERELL, T.D.A. 1908. Notes on the bee-genus Exaerete. Psyche 15:41-42.

DRESSLER, R.L. 1978a. An infrageneric classification of Euglossa, with notes on some features of special taxonomic importance (Hymenoptera; Apidae). Rev. Biol. Trop. 26(1):187-198.

DRESSLER, R.L. 1978b. New species of Euglossa from México and Central América. Rev. Biol. Trop. 26(1):167-185.

DRESSLER, R.L. 1982a. New species of Euglossa. II. (Hymenoptera: Apidae). Rev. Biol. Trop. 30(2):121-129.
DRESSLER, R.L. 1982b. Biology of the orchid bees (Euglossini). Annu. Rev. Ecol. Syst. 13:373-394.

DRESSLER, R.L. 1982c. New species of Euglossa. III. (Hymenoptera: Apidae). Rev. Biol. Trop. 30(2):131-140.

DRESSLER, R.L. 1982d. New species of Euglossa. IV. The cordata and purpurea species group (Hymenoptera: Apidae). Rev. Biol. Trop. 30(2):141-150

DRESSLER, R.L. 1985. Euglossine bees (Hymenoptera: Apidae) of Tambopata Reserved Zone, Madre de Dios, Perú. Rev. Peru. Entomol. 27(1):75-79.

ELTZ, T., WHITTEN, W.M., ROUBIK, D.W. \& LINSENMAIR, K.E. 1999. Fragrance, collection, storage, and accumulation by individual male orchid bees. J. Chem. Ecol. 25(1):157-176.

ENGEL, M.S. 2005. Family-group names for bee (Hymenoptera: Apidae). Am. Mus. Novit. 3476:1-33.

FABRICIUS, J.C. 1804. Systema Piezatorum Secundum Ordines, Genera, Species, adiectis Synonymis, Locis, Observationibus, Descriptionibus. Reichard ed., Brunsvigae [Brunswick]. 439+30 p.

GARÓFALO, C.A. \& ROZEN-JR, J.G. 2001. Parasitic behavior of Exaerete smaragdina with descriptions of its mature oocyte and larval instars (Hymenoptera: Apidae: Euglossini). Am. Mus. Nov. 3349:1-26.

HINOJOSA-DÍAZ, I.A. \& ENGEL, M.S. 2007a. Two new orchid bees of the subgenus Euglossella from Peru (Hymenoptera: Apidae). Beitr. Ent. 57(1):93-104.

HINOJOSA-DÍAZ, I.A. \& ENGEL, M.S. 2007b. A New Fossil Orchid Bee in Colombian Copal (Hymenoptera: Apidae). Am. Mus. Nov. 3589:1-7.

HOFFMANNSEGG, C.J.C. 1817. Entomologische Bemerkungen bei Gelegenheit der Abhandlungen über amerikanische Insekten. Zool. Mag. 1:8-56.

JANZEN, D.H., DE VRIES, P.J., HIGGINS, M.L. \& KIMSEY, L.S. 1982. Seasonal and site variation in Costa Rican euglossine bees at chemical baits in lowland deciduous and evergreen forests. Ecology 63(1):66-74.

LATREILLE, P.A. 1802. Histoire Naturelle, Générale et Particulière des Crustacés et des Insectes. Ouvrage faisant suite à l'histoire naturelle generale et particulière, composée par Leclerc de Buffon, et rédigé e par C.S. Sonnini, membre de plusieurs sociétés savantes. Tome troisième, Dufart ed., Paris. v.3, xii+467 p.

LEPELETIER-SAINT-FARGEAU, A.L.M. 1841. Histoire Naturelle des Insectes, Hyménoptères. Roret, Paris. v. 2, 680 p.

LEPELETIER-SAINT-FARGEAU, A.L.M. \& AUDINET-SERVILLE, J.G. 1825. In Encyclopédie Méthodique, ou par ordre de matières (G.A. Olivier, ed.). Histoire Naturelle. Insectes. Agasse ed., Paris. v. 10, pars $1,344 \mathrm{p}$.

MICHENER, C.D. 2000. The Bees of the World. Johns Hopkins University Press, Baltimore. 913 p.

MORATO, E.F. \& CAMPOS, L.A.O. \& MOURE, J.S. 1992. Abelhas Euglossini (Hymenoptera: Apidae) coletadas na Amazônia Central. Rev. Bras. Ent. 36(4):767-771.

MOURE, J.S. 1967a. Descrição de algumas espécies de Euglossinae (Hym., Apoidea). Atas Simp. Biota Amazônica 5:373-394.

MOURE, J.S. 1967b. A check-list of the known euglossine bees (Hymenoptera: Apidae). Atlas Simp. Biota Amazôn. (Zool.) 5:395-415.

MOURE, J.S. 1968. Espécies novas de Euglossa da América Central (Hymenoptera: Apidae). Boletim Univ. Fed. Paraná 3(2):13-64.

MOURE, J.S. 1969. The Central American species of Euglossa subgenus Glossura Cockerell, 1917 (Hymenoptera: Apidae). Rev. Biol. Trop. 15(2):227-247.

MOURE, J.S. 1970. The species of Euglossine bees of Central America belonging to the subgenus Euglossella (Hymenoptera, Apidae). An. Acad. Bras. Ciênc. 42(1):147-157.

MOURE, J.S. 1989a. Glossuropoda, novo subgênero de Euglossa, e duas espécies novas da Amazônia, do mesmo subgênero (Hymenoptera: Apidae). Mem. Inst. Oswaldo Cruz 84(4):387-389. 
MOURE, J.S. 1989b. Espécies novas de abelhas da região central de Minas Gerais, Brasil (Hymenoptera: Apoidea). Acta Biol. Parana 18(1-4):115-127.

MOURE, J.S. \& SCHLINDWEIN, C. 2002. Uma nova espécie de Euglossa (Euglossella) Moure do Nordeste do Brasil (Hymenoptera: Apidae). Rev. Bras. Zool. 19(2):585-588.

MYERS, J.G. 1935. Ethological observations on the citrus bee Trigona silvestriana Vachal and other neotropical bees. (Hym., Apoidea). Trans. R. Entomol. Soc. Lond. 83(1):131-142.

OLIVEIRA, M.L. 1999. Sazonalidade e horário de atividades de abelhas Euglossinae (Hymenoptera: Apidae) em florestas de terra firme na Amazônia Central. Rev. Bras. Zool. 16(1):83-90.

OLIVEIRA, M.L. 2006. Três novas espécies de abelhas da Amazônia pertencentes ao gênero Eulaema (Hymenoptera: Apidae: Euglossini). Acta Amazôn. 36(1):121-128. http://www.scielo.br/pdf/aa/v36n1/v36n1a15. pdf (último acesso em 10/10/2007).

OLIVEIRA, M.L. \& CAMPOS, L.A.O. 1996. Preferências por estratos florestais e por substâncias odoríferas em abelhas Euglossinae (Hymenoptera: Apidae). Rev. Bras. Zool. 13(4):1075-1085.

PARRA-H, A., OSPINA-TORRES, R. \& RAMÍREZ, S. 2006. Euglossa natesi n. sp., a new species of orchid bee from the Chocó region of Colombia and Ecuador (Hymenoptera: Apidae). Zootaxa 1298:29-36. http://www.mapress.com/zootaxa/2006f/z01298p036f.pdf (último acesso em 10/10/2007).

PCBAP. 1997. Plano de Conservação da Bacia do Alto Paraguai. Diagnósticos dos meios físico e bióticos, Meio físico. MMA, Brasília. v.2, tomo1, $400 \mathrm{p}$.

PEARSON, D.L. \& DRESSLER, R.L. 1985. Two years study of male orchid bee (Hymenoptera: Apidae: Euglossini) attraction to chemical baits in lowland south-eastern Peru. J. Trop. Ecol. 1(1):37-54.

PERUQUETTI, R.C., CAMPOS, L.A.O., COELHO, C.D.P., ABRANTES, C.V.M. \& LISBOA, L.C.O. 1999. Abelhas Euglossini (Apidae) das áreas de Mata Atlântica: abundância, riqueza e aspectos biológicos. Rev. Bras. Zool. 16(2):101-118.

RAMÍREZ, S. 2005. Euglossa paisa, a new species of orchid bee from the Colombian Andes (Hymenoptera: Apidae). Zootaxa 1065:51-60. http:// www.mapress.com/zootaxa/2005f/z01065p060f.pdf (último acesso em 10/10/2007).

RAMÍREZ, S. 2006. Euglossa samperi, a new species of orchid bee from the Ecuadorian Andes (Hymenoptera: Apidae). Zootaxa 1272:61-68. http:// www.mapress.com/zootaxa/2006f/z01272p068f.pdf (último acesso em 10/10/2007).

RAMÍREZ, S., DRESSLER, R.L. \& OSPINA, M. 2002. Abejas euglossinas (Hymenoptera: Apidae) de la región Neotropical: lista de especies con notas sobre su biología. Biota Colombiana 3(1):7-118.

RASMUSSEN, C. \& SKOV, C. 2006. Description of a new species of Euglossa (Hymenoptera: Apidae: Euglossini) with notes on comparative biology. Zootaxa 1210:53-67. http://www.mapress.com/zootaxa/2006f/ z01210p067f.pdf (último acesso em 10/10/2007).

REBÊLO, J.M.M. \& MOURE, J.S. 1995 As espécies de Euglossa Latreille do nordeste do Estado de São Paulo (Apidae: Euglossinae). Rev. Bras. Zool. 12(3):445-466.

ROUBIK, D. 2004. Sibling species of Glossura and Glossuropoda in the Amazon region (Hymenoptera: Apidae: Euglossini). J. Kans. Entomol. Soc. 77(3):235-253.

ROUBIK, D.W. \& ACKERMAN, J.D. 1987. Long-term ecology of euglossine orchid-bees (Apidae: Euglossini) in Panama. Oecologia 73(3):321-333.

ROUBIK, D.W. \& HANSON, P.E. 2004. Orchid bees from tropical America. Biology and field guide. INBio Press, Santo Domingo de Heredia.

SILVA, F.S. \& REBÊLO, J.M.M. 1999. Euglossine bees (Hymenoptera: Apidae) of Buriticupu, Amazonia of Maranhão, Brazil. Acta Amazôn. 29(4):587-599.

WESTWOOD, J.O. 1840. An introduction to the modern classification of insects; found on the natural habits and corresponding organization of the different families. Longman, London, v.2.

WILLIAMS, N.H. \& DODSON, C.H. 1972. Selective attraction of male euglossine bees to orchid floral fragrances and its importance in long distance pollen flow. Evolution 26(1):84-95.

Data Received 18/10/07 Revised 01/04/08 Accepted 23/04/08 